\title{
The impact of chronic conditions of care recipients on the labour force participation of informal carers in Australia: which conditions are associated with higher rates of non-participation in the labour force?
}

Deborah Schofield ${ }^{1}$, Michelle Cunich ${ }^{1 *}$, Rupendra Shrestha ${ }^{1}$, Megan Passey ${ }^{2}$, Simon Kelly ${ }^{3}$, Robert Tanton ${ }^{3}$ and Lennert Veerman ${ }^{4}$

\begin{abstract}
Background: Little is known about the effects of personal and other characteristics of care recipients on the behaviour of carers. The aim of this study is to examine the association between the main chronic (disabling) condition of care recipients and the likelihood of their (matched) primary carers aged 15-64 years being out of the labour force.

Methods: We conducted a retrospective analysis of cross-sectional data from the Australian Bureau of Statistics 2009 Survey of Disability, Ageing and Carers (SDAC) for people aged 15-64 years. We estimated the rates of exit from the labour force for primary carers and non-carers; rates of chronic disease occurrence for care recipients living with their main carers; odds ratios of primary carers being out of the labour force associated with the main chronic condition of their care recipient who lives with them.

Results: From the 2009 SDAC, we identified 1,268 out of 37,186 eligible participants who were primary carers of a care recipient who lived with them. Of these, 628 (49.5\%) were out of the labour force. Most common diseases of care recipients were: back problems (12\%); arthritis and related disorders (10\%); diseases of the nervous system (such as multiple sclerosis, epilepsy, cerebral palsy) (7.4\%); and conditions originating in the perinatal period or congenital malformations, deformations and chromosomal abnormalities (5.1\%). When adjusted for age, sex, education and whether have a long term chronic condition of informal carers, the five conditions of care recipients associated with the highest odds of their carers being out of the labour force were: head injury/acquired brain damage; neoplasms, blood diseases, disorders of the immune system; leg/knee/foot/hip damage from injury/ accident; dementia, Parkinson's disease, Alzheimer's disease; and diseases of the musculoskeletal system and connective tissue (osteoporosis).

(Continued on next page)
\end{abstract}

\footnotetext{
* Correspondence: michelle.cunich@ctc.usyd.edu.au

${ }^{1}$ NHMRC Clinical Trials Centre and School of Public Health, Sydney Medical

School, The University of Sydney, Sydney, Australia

Full list of author information is available at the end of the article
} 
(Continued from previous page)

Conclusions: This study identifies the type of conditions that have the greatest impact on the labour force participation of informal carers - previously unavailable information for Australia. Australia, like most developed countries, is facing several skills shortages and an ageing population. These governments will need to adopt novel and more wholistic approaches to increase the labour force participation of diverse groups. Informal carers are one such group.

Keywords: Chronic disease, Chronic disabling conditions, Labour force participation, Informal carers, Recipients of care, Household survey data, Cross-sectional study

\section{Background}

Globally, the number of children with a chronic illness or disability and older people needing care is projected to increase significantly in the next 20 years [1-3]. Focusing on older people, $13 \%$ of people aged 60 or older currently need long term care. However, the total number of older people with care needs is projected to almost treble from 101 to 277 million between 2010 and 2050 [4]. This care can be provided in both formal and informal ways: (a) formally by people employed in the health care sector, and (b) informally by relatives or friends of the recipient of care [5]. Informal carers are generally not paid for their caring responsibilities but these tasks can have an impact on the capability of carers to undertake paid employment [6]. In this paper, we focus on the impact of chronic illness or disability of care recipients on the labour force participation of informal caregivers.

Informal carers of people with a chronic illness or disability constituted $12 \%$ of the Australian population (or 2.6 million people) in 2009 [7], and this number is expected to increase due to greater demand for such care. In adults, greater demand is largely due to Australia's ageing population [1] and related increasing rates of several chronic diseases [8], such as diabetes and dementia [9]. In children, the reasons for greater demand are more complex; there has been an increase in the rate of preterm births (babies born less than 37 gestational weeks) $[10,11]$ and increases in the survival rates of all preterm babies, even extremely preterm babies (born less than 28 gestational weeks), with an associated increase in disability amongst those survivors [12]. The sizeable devotion of Australians to giving informal care has significant ramifications for national labour force participation, GDP, the tax base and welfare costs (and thus the budget balance), in addition to the individual financial, social, emotional and health costs of those carers.

Recognising the current (and projected) 'crisis' in informal care provision, there is a large body of literature on the impact of informal caregiving (full- or part-time basis) on labour force participation. These studies have found that informal carers tend to have lower rates of labour force participation compared to non-carers [6,13-16]. A recent cross-sectional study involving Australians aged 45 and older $(n=265,515)$ demonstrated that full-time carers are not only more likely to be out of the labour force than noncarers (and part-time carers) but more likely to have lower household income than non-carers. Just over $40 \%$ of noncarers had an annual household income of more than $\$ 70,000$, whereas only $12.6 \%$ of full-time carers had the same level of income. These impacts were also found to be greater for carers who were themselves in poorer health [17]. A study using a single wave of the Household Income and Labour Dynamics in Australia (HILDA) survey data (2008) [18] confirms these prior findings. This study reports that being a main carer reduces the probability of employment by around 12 percentage points for both males and females, regardless of whether or not the carer lives with the recipient of care.

Gray and Edwards (2009), using a nationally representative sample of female carers in receipt of government assistance (2006 Families Caring for a Person with a Disability Survey), examined the impact of personal and care-related characteristics on the likelihood of maintaining employment [19]. They found that although carers had a lower employment rate than non-carers, over half of those who were not employed reported they would like to be in paid employment. The main factors associated with the lower rate of employment for female carers were having a low level of educational attainment, poorer health, caring for someone on a full time basis, caring for a child who has a disability, and not having someone outside the household who can provide assistance. Qu et al. (2012), using the 2009 Survey of Disability, Ageing and Carers (SDAC) and 2006 (Australian) Census data, examined the characteristics of parent carers and their son or daughter with a disability who lives with them [20]. With regard to economic outcomes, they found that older women (aged 65 years or older) caring for their adult children were less likely to participate in the labour force and had a lower personal income than others. Thus older women caring for a son or daughter with a disability (particularly female sole parents) were found to be disadvantaged in relation to financial provision for their own retirement.

Few studies have examined the impact of informal caregiving on the economic circumstances of carers (and their families) using Australian longitudinal data. Bittman et al. 
(2007) examined the effects of informal caregiving on carers' employment, income and earnings using four waves of HILDA (2001-04) [21]. They found that carers were more likely to reduce their hours of work or exit from the labour force and earned less on average than non-carers. Leigh (2009) examined changes in labour market outcomes for carers as their caring commitments changed using a longer span of HILDA data (i.e. 2001-2007) [22] and found that caregiving had a negative effect on the labour force participation of carers. Falkiner (2011), using the latest waves of HILDA (waves 5-9 i.e. 2005-2009), examined the characteristics of people who become carers including the age at which people have the greatest risk of becoming carers for the first time [23]. This study provides estimates of the hazard of entering caregiving but it does not explore how this decision affects economic outcomes of carers (and families) after doing so.

Few studies, however, have examined the type of chronic conditions of care recipients that have the greatest impact on the labour force participation of informal carers, and even fewer on the economic consequences of health interventions which may, indirectly, improve the income of informal carers and government finances [8]. In this paper, we address this paucity in research in relation to the former. Specifically, we undertake a retrospective cross-sectional analysis (using the 2009 SDAC) to examine the associations between chronic (disabling) conditions of care recipients living with their primary (informal) carers and the likelihood of these carers of working age (i.e. aged 15-64 years) being out of the labour force.

\section{Methods}

Data on people aged 15-64 years from the Australian Bureau of Statistics (ABS) 2009 Survey of Disability, Ageing and Carers (SDAC) [24] was used to identify the main chronic (disabling) condition of each (main) care recipient living with their matched primary informal carer(s). The use of these data was approved by the Australian Bureau of Statistics Microdata Review Panel.

\section{Identifying informal carers in the 2009 SDAC}

There are several categories of carers in the 2009 SDAC. Carers were identified as those who indicated they were:

a) a primary carer of a usual resident (i.e. lives with) care recipient (care recipient identified and carer identified);

b) other primary carer of a usual resident care recipient;

c) primary carer of a non-usual resident (i.e. does not live with) care recipient; or

d) other carer.
However, information on both the main care recipient and carer (such as age, sex, education, labour force participation, chronic conditions, and duration of care) needed for this study was only available for main usual resident care recipients who could be matched to primary carers. In particular, information on the main disabling chronic condition of care recipients was only available for those who were living with their primary carers. For this reason, our analysis focuses only on primary carers of care recipients who live with them (i.e. categories (a) and (b) above).

A working definition of primary carers is provided by the ABS (2010) as follows: "A primary carer is a person who provides the most informal assistance, in terms of help or supervision, to a person with one or more disabilities or aged 60 years and over. The assistance has to be ongoing, or likely to be ongoing, for at least six months and be provided for one or more of the core activities (communication, mobility and self-care)" (p. 34).

The labour force was defined as people who are employed or unemployed but looking for work.

The 2009 SDAC contains information on the demographic and socioeconomic characteristics of all people surveyed (including age, sex, education, labour force participation) as well as their health and wellbeing (such as chronic conditions). For care recipients, there is detailed information on several aspects of their health and care arrangements, including the number and type of chronic (and disabling) conditions, number of carers they have, whether they are living with carer(s), and duration of care. This paper focuses only on the main disabling condition of care recipients for the analysis.

The survey data are weighted by the ABS to address the issue of unequal probability of selection in the survey, and to make the survey data a true representation of the Australian population. We used these weightings in our analysis to estimate the prevalence of chronic conditions of care recipients living with their carers for the entire Australian population needing care.

We used logistic regression analysis, adjusted for age and sex of the primary carer, to estimate the odds ratios (ORs) of them being out of the labour force associated with each (main) disabling condition of their care recipient who lives with them, using "not a carer" as the reference group. ORs are presented with 95\% confidence intervals. Significance was set at $\mathrm{P}<0.05$. All analyses were conducted using SAS, version 9.3 (SAS Institute, Cary, NC, USA).

\section{Results}

Of the 72,075 people surveyed in the 2009 SDAC, $37,186(51.6 \%)$ were in the 15-64 years age group. Of these, 1,268 (3.4\%) were identified as primary (informal) carers. Of the primary carers identified of working age, 
$628(49.5 \%)$ stated they were caregiving and out of the labour force, with the remaining 640 (50.5\%) stating they were caregiving and in the labour force (Table 1).

All primary carers identified could be matched to a main care recipient who lived with them - information needed to identify the main disabling condition of care recipients. The most common disabling conditions among care recipients were: back problems, arthritis and related disorders, diseases of the nervous system (such as multiple sclerosis, epilepsy, and cerebral palsy), autism and related disorders, and congenital conditions (Table 2). Based on the proportion of primary carers out of the labour force, the most work-limiting conditions for caregivers were: head injury/acquired brain damage, schizophrenia, diseases of the musculoskeletal system and connective tissue (osteoporosis), dementia/Parkinson's disease/Alzheimer's disease, and endocrine/nutritional and metabolic disorders (thyroid, diabetes and high blood pressure) (Table 2). 60-70\% of carers who were caring for someone with one of these conditions were not in the labour force.

Crude ORs (not shown) revealed a significant association with primary carers being out of the labour force for all chronic (disabling) conditions of care recipients, except for Attention Deficit Disorder/hyperactivity, arm/ hand/shoulder damage from injury or accident, and other soft tissue/muscle disorders. After adjusting for the carer's age, sex, education and whether they have a chronic condition themselves, all associations apart from schizophrenia and the three condition groups noted above remained significant (Table 3).

\section{Discussion}

Using population data from the ABS, we estimated that 215,153 Australians of working age were missing from the labour force and giving care to a relative or friend living with them who had a chronic (disabling) condition in 2009. Back problems, arthritis and related disorders, diseases of the nervous system (such as multiple sclerosis, epilepsy, and cerebral palsy), mental and behavioural disorders (autism, congenital conditions, and intellectual and developmental disorders/mental retardation/intellectual disabilities) and diseases of the circulatory system (stroke and hypertension) were the five most common conditions among those care recipients and accounted for $47 \%$ of total caregiving. This profile is similar to the profile of disorders accounting for most Disability Support Pension payments. Musculoskeletal disorders, psychological problems, and diseases of the circulatory system are the top three long term conditions reported by recipients of the disability pension (Centrelink, Performance and Information Branch, data request BI3268: health conditions associated with sickness benefits and Disability Support Pension, 13 Jan
2006). The five diseases of care recipients associated with the highest odds of carers being out of the labour force were: head injury/acquired brain damage, schizophrenia, diseases of the musculoskeletal system, dementia/ Parkinson's disease/Alzheimer's disease, and endocrine/nutritional and metabolic disorders. $60-70 \%$ of primary carers who were out of the labour force were caring for someone with one of these conditions.

The study has a number of limitations. Firstly, the impact of chronic conditions of care recipients on the labour force participation of carers relies on selfreported data on the care recipient's main disabling condition. Although self-assessed health is regarded as a valid measure of health status [25], there is possible bias in the results as not all self-reported conditions from the 2009 SDAC (or similar surveys) have been appraised in terms of reliability/validity. Secondly, as the 2009 SDAC are cross-sectional data, it is only possible to identify associations rather than causal relationships between variables. Finally, the 2009 SDAC does not capture mortality data, and therefore the study could not estimate the impact of mortality (care recipient or carer) on labour force participation.

Previous governments have focused on increasing labour force participation via economic incentives targeting younger and older workers separately. For new parents, there have been improvements in parental leave allowances for women and men in all workplaces, as well as commencement of the Commonwealth Government's paid parental leave which provides payments for up to 18 weeks after the birth or adoption of a child [26]. For older workers, the $15 \%$ tax on lump sums and pensions from superannuation schemes after the age of 60 years has been removed [27]. There is also the Age Discrimination Act 2004 which provides job protection for all Australian workers [28]. However, these broadreaching incentives to help people either return to, or remain in, paid employment fail to take into account one of the main reasons people have to leave the labour force abruptly: the caring needs of a relative or friend. Moreover, there needs to be more achieved in terms of policy design - we need to address the rise of chronic conditions which are associated with most of the low labour force participation of carers. Until then, these incentives are unlikely to have a major impact on the labour force participation of caregivers.

Traditionally, health policy has focused on the provision of health care (and services) to improve the health of citizens for its own sake, and employment policy (and setting of priorities) has been largely conducted in isolation from health policy. However, recent Australian Government health reforms seem to echo the notion that "good health policy is part of good economic policy" as noted in Russell et al. (2008) [29]. This philosophy naturally 
Table 1 People not in the labour force by carer status, age group and sex, of 37186 Australians aged 15-64 years surveyed in 2009

No. not in labour force in survey group

\begin{tabular}{|c|c|c|c|c|c|c|c|c|c|c|c|c|}
\hline \multirow[t]{3}{*}{ Age group (years) } & \multicolumn{4}{|c|}{ Men } & \multicolumn{4}{|c|}{ Women } & \multicolumn{4}{|c|}{ All } \\
\hline & \multicolumn{2}{|c|}{ Primary carers* } & \multicolumn{2}{|c|}{ Not carers } & \multicolumn{2}{|c|}{ Primary carers* } & \multicolumn{2}{|c|}{ Not carers } & \multicolumn{2}{|c|}{ Primary carers* } & \multicolumn{2}{|c|}{ Not carers } \\
\hline & $n$ & Wt n (\%) ${ }^{\wedge}$ & $n$ & Wt n (\%) ${ }^{\wedge}$ & $\mathrm{n}$ & Wt n (\%) ${ }^{\wedge}$ & $n$ & Wt n (\%) & $\mathrm{n}$ & Wt n (\%) ${ }^{\wedge}$ & $\mathrm{n}$ & Wt n (\%) ${ }^{\wedge}$ \\
\hline $15-24$ & 6 & 2536 (34.3) & 1083 & $391330(27.7)$ & 20 & $5842(54.4)$ & 1061 & $379885(28.3)$ & 26 & $8378(46.2)$ & 1515 & $771215(28.0)$ \\
\hline $25-34$ & 3 & $1802(18.6)$ & 222 & $88338(6.2)$ & 55 & $17947(43.5)$ & 810 & $289033(21.5)$ & 58 & 19749 (38.8) & 629 & 377371 (13.6) \\
\hline $35-44$ & 23 & 9492 (37.8) & 228 & $79501(5.9)$ & 115 & $40824(46.6)$ & 810 & $268616(21.1)$ & 138 & $50316(44.7)$ & 505 & 348117 (13.3) \\
\hline $45-54$ & 43 & $14606(30.4)$ & 312 & $103789(8.5)$ & 109 & $37531(46.1)$ & 603 & 200817 (17.5) & 152 & $52137(44.7)$ & 527 & 304606 (12.8) \\
\hline $55-64$ & 83 & $26783(51.6)$ & 731 & $242927(24.8)$ & 172 & $57790(70.1)$ & 1261 & $408195(44.5)$ & 254 & $84573(62.9)$ & 575 & $651122(34.3)$ \\
\hline Total & $158(42.8)$ & 55219 (42.6) & $2576(14.2)$ & $905885(14.2)$ & $471(52.4)$ & 159934 (52.7) & 4545 (25.5) & 1546546 (25.6) & $628(49.5)$ & $215153(49.7)$ & $7121(19.8)$ & $2452431(19.7)$ \\
\hline
\end{tabular}

Wt $\mathrm{n}=$ weighted sample (reflect Australian population).

* Primary carers = Primary carers of usual resident (i.e. lives with) care recipients.

$\wedge$ The proportion of each cohort not in the labour force. 
Table 2 Prevalence of main disabling conditions of care recipients living with carers and the labour force participation of primary carers among 37186 Australians aged 15-64 years, 2009

\begin{tabular}{|c|c|c|c|c|}
\hline \multirow[t]{2}{*}{ Main disabling condition of care recipient } & \multicolumn{2}{|r|}{ Total } & \multicolumn{2}{|c|}{ Not in labour force } \\
\hline & $\begin{array}{l}\text { No. in } \\
\text { survey }\end{array}$ & $\begin{array}{l}\text { Weighted } \\
\text { number (\%) }\end{array}$ & $\begin{array}{l}\text { No. in } \\
\text { survey }\end{array}$ & $\begin{array}{l}\text { Weighted } \\
\text { number (\%) }\end{array}$ \\
\hline Not a carer & 35918 & $12427469(96.6)$ & 7121 & $2456120(19.8)$ \\
\hline Primary carer of UR recipient of care & 1268 & $433338(3.4)$ & 628 & $215477(49.7)$ \\
\hline \multicolumn{5}{|l|}{ Main disabling condition of UR recipient of care: } \\
\hline Neoplasms (tumours/cancers), blood diseases, disorders of immune system & 33 & $10535(3.4)$ & 19 & $6392(57.6)$ \\
\hline Endocrine/nutritional and metabolic disorders (thyroid, diabetes, high blood pressure) & 15 & $5275(1.2)$ & 9 & $3234(60.0)$ \\
\hline Schizophrenia & 13 & $4776(1.1)$ & 8 & $2792(61.5)$ \\
\hline Depression/mood affective disorders & 38 & $13401(3.1)$ & 20 & $6354(52.6)$ \\
\hline Phobic and anxiety disorders, nervous tension/stress & 39 & $13439(3.1)$ & 15 & $5686(38.5)$ \\
\hline Intellectual and developmental disorders, mental retardation/intellectual disabilities & 62 & $18943(4.4)$ & 34 & $10300(54.8)$ \\
\hline Autism and related disorders (including Rett's syndrome and Asperger's syndrome) & 88 & $26693(6.2)$ & 36 & $11210(40.9)$ \\
\hline ADD/hyperactivity & 28 & $9195(2.1)$ & 11 & $2955(39.3)$ \\
\hline Other mental and behavioural disorders & 59 & $19756(4.6)$ & 29 & $9905(49.2)$ \\
\hline Dementia, Parkinson's disease, Alzheimer's disease & 29 & $9644(2.2)$ & 18 & $6037(60.1)$ \\
\hline $\begin{array}{l}\text { Other diseases of the nervous system (MS, epilepsy, cerebral palsy, paralysis, } \\
\text { chronic fatigue syndrome) }\end{array}$ & 87 & $32070(7.4)$ & 34 & $12157(39.1)$ \\
\hline Diseases of the eye and adnexa (retinal disorders/defects, glaucoma, sight loss) & 22 & $9539(2.2)$ & 9 & $4215(40.9)$ \\
\hline Diseases of the ear and mastoid process (deafness/hearing loss congenital) & 44 & $14330(3.3)$ & 21 & $6827(47.7)$ \\
\hline Heart diseases & 28 & $9133(2.1)$ & 15 & $4666(53.6)$ \\
\hline Diseases of the circulatory system (stroke and hypertension) & 51 & $18058(4.2)$ & 28 & $10380(54.9)$ \\
\hline Diseases of the respiratory system (emphysema, asthma) & 39 & $13568(3.1)$ & 20 & $7401(51.3)$ \\
\hline Arthritis and related disorders & 123 & $43291(10.0)$ & 57 & $19364(46.3)$ \\
\hline Back problems (dorsopathies) & 153 & $51972(12.0)$ & 82 & $28709(53.6)$ \\
\hline Other soft tissue/muscle disorders (including Rheumatism) & 15 & $6089(1.4)$ & 7 & $2452(46.7)$ \\
\hline Diseases of the musculoskeletal system and connective tissue (osteoporosis) & 31 & $11115(2.6)$ & 19 & $6534(61.3)$ \\
\hline $\begin{array}{l}\text { Conditions originating in perinatal period or congenital malformations, } \\
\text { deformations and chromosomal abnormalities }\end{array}$ & 59 & $22006(5.1)$ & 25 & $10110(42.4)$ \\
\hline Head injury/acquired brain damage & 42 & $13409(3.1)$ & 28 & $9842(66.7)$ \\
\hline Leg/knee/foot/hip damage from injury/accident & 46 & $14665(3.4)$ & 26 & $8628(56.5)$ \\
\hline Other damage from injury/accident (arm/hand/shoulder damage) & 24 & $7447(1.7)$ & 8 & $2299(33.3)$ \\
\hline Other long term condition & 100 & $34988(8.1)$ & 50 & $17028(50.0)$ \\
\hline
\end{tabular}

leads to the need to address the country's increasing burden of preventable illnesses/diseases, such as diabetes and cardiovascular disorders, with the highest care demands, and reduce the occurrence of accidents and injuries.

The challenges faced by carers as a whole seem to be from pressures already in the health sector and the lack of formal measures ensuring appropriate workplace flexibility for carers. Whilst there are public and private care services for those with a disability, chronic condition, or frail aged (such as residential and aged care facilities) and respite care (see, for details about the Government's
National Respite for Carers Program, [30]), there are more people in need of these services than is available, resulting in delayed or constrained access [31]. Moreover, the policy direction taken in the last 20 years has been to move away from institutional forms of care to "ageing in place" i.e. community-based care [32].

The Australian Government provides two forms of financial supports for carers: Carer Payment and Carer Allowance. The former is an income support payment for people who personally provide regular (continuous) care in the home for someone with a severe disability, illness, or frail aged. It is a payment for carers who are 
Table 3 Main disabling conditions of care recipients living with carers associated with carers being out of the labour force

\begin{tabular}{|c|c|c|c|}
\hline \multirow{2}{*}{$\begin{array}{l}\text { Condition } \\
\text { Neoplasms (tumours/cancers), blood } \\
\text { diseases, disorders of immune system }\end{array}$} & \multirow{2}{*}{$\begin{array}{l}\text { Adjusted OR* } \\
6.547\end{array}$} & \multicolumn{2}{|c|}{$95 \% \mathrm{Cl}$} \\
\hline & & 2.844 & 15.076 \\
\hline $\begin{array}{l}\text { Endocrine/nutritional and metabolic } \\
\text { disorders (thyroid, diabetes, high } \\
\text { blood pressure) }\end{array}$ & 4.239 & 1.303 & 13.787 \\
\hline Schizophrenia & 3.933 & 0.709 & 21.817 \\
\hline Depression/mood affective disorders & 2.249 & 1.110 & 4.557 \\
\hline $\begin{array}{l}\text { Phobic and anxiety disorders, } \\
\text { nervous tension/stress }\end{array}$ & 2.398 & 1.100 & 5.231 \\
\hline $\begin{array}{l}\text { Intellectual and developmental } \\
\text { disorders, mental retardation/ } \\
\text { intellectual disabilities }\end{array}$ & 4.373 & 2.494 & 7.666 \\
\hline $\begin{array}{l}\text { Autism and related disorders } \\
\text { (including Rett's syndrome and } \\
\text { Asperger's syndrome) }\end{array}$ & 3.227 & 1.906 & 5.462 \\
\hline ADD/hyperactivity & 1.429 & 0.633 & 3.225 \\
\hline Other mental and behavioural disorders & 3.467 & 1.953 & 6.155 \\
\hline $\begin{array}{l}\text { Dementia, Parkinson's disease, } \\
\text { Alzheimer's disease }\end{array}$ & 4.932 & 1.845 & 13.186 \\
\hline $\begin{array}{l}\text { Other diseases of the nervous } \\
\text { system (MS, epilepsy, cerebral palsy, } \\
\text { paralysis, chronic fatigue syndrome) }\end{array}$ & 2.527 & 1.569 & 4.071 \\
\hline $\begin{array}{l}\text { Diseases of the eye and adnexa } \\
\text { (retinal disorders/defects, glaucoma, } \\
\text { sight loss) }\end{array}$ & 2.716 & 1.078 & 6.845 \\
\hline $\begin{array}{l}\text { Diseases of the ear and mastoid } \\
\text { process (deafness/hearing loss } \\
\text { congenital) }\end{array}$ & 2.704 & 1.307 & 5.593 \\
\hline Heart diseases & 3.605 & 1.651 & 7.872 \\
\hline $\begin{array}{l}\text { Diseases of the circulatory system } \\
\text { (stroke and hypertension) }\end{array}$ & 3.759 & 1.919 & 7.363 \\
\hline $\begin{array}{l}\text { Diseases of the respiratory system } \\
\text { (emphysema, asthma) }\end{array}$ & 3.402 & 1.565 & 7.391 \\
\hline Arthritis and related disorders & 2.488 & 1.628 & 3.803 \\
\hline Back problems (dorsopathies) & 4.346 & 2.945 & 6.414 \\
\hline $\begin{array}{l}\text { Other soft tissue/muscle disorders } \\
\text { (including Rheumatism) }\end{array}$ & 2.385 & 0.849 & 6.695 \\
\hline $\begin{array}{l}\text { Diseases of the musculoskeletal } \\
\text { system and connective tissue } \\
\text { (osteoporosis) }\end{array}$ & 4.606 & 2.134 & 9.941 \\
\hline $\begin{array}{l}\text { Conditions originating in perinatal } \\
\text { period or congenital malformations, } \\
\text { deformations and chromosomal } \\
\text { abnormalities }\end{array}$ & 2.605 & 1.434 & 4.732 \\
\hline Head injury/acquired brain damage & 8.415 & 4.137 & 17.116 \\
\hline $\begin{array}{l}\text { Leg/knee/foot/hip damage from } \\
\text { injury/accident }\end{array}$ & 5.781 & 2.919 & 11.451 \\
\hline $\begin{array}{l}\text { Other damage from injury/accident } \\
\text { (arm/hand/shoulder damage) }\end{array}$ & 1.062 & 0.400 & 2.816 \\
\hline Other long term condition & 0.529 & 0.497 & 0.564 \\
\hline
\end{tabular}

$\mathrm{OR}=$ odds ratio. *Adjusted for age, sex, education of primary carer as well as whether they have a long term health condition. The reference group was "non-carer". unable to participate in the labour force full time due to their caregiving role. Eligibility for this payment includes satisfying an income and assets test. It also depends on the level of impairment of the care recipient $[19,33]$. The latter is a supplementary payment for carers who provide additional daily care and attention for someone with a disability or medical condition, or frail aged [33]. Eligibility for this payment does not include income or asset testing. Almost everyone who receives Carer Payment also receives Carer Allowance. Currently, the single rate for Carer Payment is $\$ 766.00$ per fortnight and the couple rate for this payment is $\$ 577.40$ per fortnight. Carer Allowance is currently $\$ 118.20$ per fortnight. Additionally, an annual payment of $\$ 600$ is payable for each child cared for under the age of 16 years [33].

There is limited information on the impact of receiving carer payments on carers' labour force participation and employment. Gray and Edwards (2009) examined the labour force participation of female carers, taking into account whether they were receiving carer payments or not [19]. (Leigh (2010)[22] only uses receipt of government payments for carers to identify carers in HILDA). Gray and Edwards (2009) reported the employment rate of female carers who received Carer Allowance only to be $43.1 \%$ (11\% of whom were in full time employment) whereas the employment rate of carers who received Carer Payment only was $20.5 \%$ (less than $1 \%$ were in full time employment). Although these relationships were significant from the estimated regression models, there was no significant relationship between type of carer's payment received and the desire to commence work. Availability, access to, and quality of suitable care services and supports for carers (such as financial supports, and having someone to help provide care at short notice) can affect working carers' chances of being able to integrate work and care successfully. Information on the type and amount of government assistance received by carers (i.e. the exact amount of Carer Payment and Carer Allowance) is not available in the 2009 SDAC; however, how this impacts on work and caregiving decisions is an issue requiring further research.

Employment policy in Australia and whether working carers (of adult people) have suitable forms of support available in work life may also need further attention. Working parents and carers are (legally) protected from discrimination when attempting to balance their work schedules with family and caring responsibilities. Under the Equal Opportunity Act 2010, employers have a positive responsibility to take practical and comparable measures to remove discrimination, sexual harassment and victimisation from their workplace (such as bullying and intimidation by other employees; an employee being denied a promotion or being moved to a position with lower responsibility; dismissal from employment; an employee being denied additional contract work) as much as possible. The Act applies to 
employers (organisations) of all sizes, includes all types of workers, and is relevant to all stages of employment. Thus there are legal protections in place to enable carers to manage their work and caring responsibilities effectively [34]. Thus the challenges seem to be in relation to whether (a) workers feel they are able to discuss any difficulties they are facing with employers at the point they occur, and (b) employers are able (and it is financially viable to do so) to generate the degree of workplace flexibility (flexible work hours, part-time work or paid/unpaid care leave hours) required to meet the personal needs of their workers who are also carers.

While $54 \%$ of all carers are women [35], recent studies have shown that men are taking on caring roles more often than was previously assumed, with a larger number of men being primary carers than women in the age group 65 years or older in Australia [36] which is driven, in part, by the longer life expectancy of women and the increasing prevalence of people with dementia and other cognitive disorders [37]. As noted in this study, caregiving has negative effects such as reduced labour force participation and lower household income among all carers. However, previous studies have also demonstrated that male and female carers differ in the way they seek to manage work and caregiving. Women more often reduce their hours of work or relinquish work when caregiving [36] and thus female carers experience additional risks in terms of career development and income compared to male carers $[17,21]$. This study provides support for the Australian Government's current health proposals which include improving the opportunities for working-age carers to participate in the labour force at a desired level [38]. With persistent skills shortages and an ageing population requiring more care in the future, the Government will need to continue on its path of adopting a more targeted (but wholistic) approach to increasing the labour force participation of its working-age population. Special attention will need to be given to the challenges faced by important subgroups. Informal carers are one such group.

\section{Conclusions}

This study identifies the type of conditions that have the greatest impact on the labour force participation of carers information previously unavailable. Given the challenges facing Australia and other developed countries (such as severe skills shortages, an ageing population, rising health care costs), successive governments will need to adopt fresh and more wholistic approaches to increase the labour force participation of different subgroups, including carers.

\section{Competing interests}

This study is part of continuing research funded by a National Health and Medical Research Council (NHMRC) Partnership Project (APP 1055037), Pfizer Australia and Carers Australia. All authors are independent from the funding sources.

\section{Authors' contributions}

DS conceived the study, and contributed to its design and coordination. DS also led drafting of the manuscript. MC contributed to the design of the study, drafting the manuscript, and performed the statistical analysis. RS contributed to the design of the study, and provided expert advice on statistical modelling. MP and LV contributed to the design of the study, and provided expert advice on the long- and short-impacts of chronic conditions. SK and RT contributed to the design of the study, and provided expert advice on carers. All authors contributed to interpretation of the results. All authors read and approved the final manuscript.

\section{Acknowledgements}

This study is part of ongoing research funded by a National Health and Medical Research Council (NHMRC) Partnership Project (APP 1055037), Pfizer Australia and Carers Australia. All authors are independent from the funding sources.

\section{Author details}

${ }^{1}$ NHMRC Clinical Trials Centre and School of Public Health, Sydney Medical School, The University of Sydney, Sydney, Australia. ${ }^{2}$ University Centre for Rural Health - North Coast, School of Public Health, University of Sydney, Lismore, NSW, Australia. ${ }^{3}$ National Centre for Social and Economic Modelling, University of Canberra, Canberra, ACT, Australia. ${ }^{4}$ School of Population Health, University of Queensland, Brisbane, Queensland, Australia.

Received: 5 February 2014 Accepted: 30 May 2014

Published: 5 June 2014

\section{References}

1. Percival R, Kelly S: Who's going to care? Informal care and an ageing population. Canberra: NATSEM; 2004.

2. Disability Rights Commission, Equal Opportunities Commission, Carers UK: The future: who carers? London: University of Leeds; 2006

3. Pickard L, Wittenberg R, Comas-Herrara A, King D, Malley J: Care by spouses, care by children: projections of informal care for older people in England to 2031. Social Policy and Society 2007, 6(3):353-366.

4. Dementia to drive global leap in number of elderly needing care. [http:// www.reuters.com/article/2013/09/19/us-alzheimers-idUSBRE9810Y820130919]

5. Productivity Commission: Caring for older Australians, Report No 53, Final Inquiry Report. Canberra: Commonwealth of Australia; 2011

6. Carmichael F, Charles S: The opportunity costs of informal care: does gender matter? J Health Econ 2003, 22(5):781-803.

7. Australian Bureau of Statistics: Survey of disability, ageing and carers 2009 Canberra: Australian Bureau of Statistics; 2012. Volume Cat. No. 4430.0.

8. Begg SJ, Vos T, Barker B, Stanley L, Lopez AD: Burden of disease and injury in Australia in the new millennium: measuring health loss from diseases, injuries and risk factors. Med J Aust 2008, 188(1):36-40.

9. Schofield D, Passey M, Earnest A, Gloor I, Shrestha R: Are we getting healthier as we grow older? Implications for babyboomer labor force participation. Ann NY Acad Sci 2007, 1114:230-240.

10. Lancaster P, Huang J, Pedisich E: Australia's mothers and babies 1991, ANPS Unit. Canberra: Australian Institute of Health and Welfare (AlHW); 1994

11. Li Z, McNally L, Hilder L, Sullivan EA: Australia's mothers and babies 2009, Perinatal statistics series no 25 Cat no PER 52. Sydney: AlHW National Perinatal Epidemiology and Statistics Unit; 2011.

12. Doyle L, Roberts $G$, Anderson PJ: Outcomes at age 2 years of infants $<28$ weeks' gestational age born in Victoria in 2005. Pediatrics 2010, 156(1):49-53.

13. Lee C, Gramotnev H: Transitions into and out of caregiving: Health and social characteristics of mid-age Australian women. Psychol Health 2007, 22(2):193-209.

14. Heitmueller A, Michaud P: Informal care and employment in England: evidence from the British household panel survey, IZA discussion paper 2010. Bonn: IZA; 2006.

15. Pavalko EK, Artis JE: Women's caregiving and paid work: causal relationships in late midlife. The Journals of Gerontology 1997, $52 \mathrm{~b}(4 \mathrm{~s}): 170-179$.

16. Speiss CK, Schnieder U: Interactions between care-giving and paid work hours. Ageing Soc 2003, 23:41-68.

17. Schofield D, Shrestha R, Callander E, Byles J, Kimman M: Costs of being a carer: labour force participation and lost earnings among older workingaged Australians. Aust N Z J Public Health 2013, 37(2):192-193. 
18. Nguyen $\mathrm{H}$, Connelly L: The effect of unpaid caregiving intensity on labour force participation: results from a multinomial endogenous treatment mode. Soc Sci Med 2014, 100:115-122.

19. Gray M, Edwards B: Determinants of the labour force status of female carers. Australian Journal of Labour Economics 2009, 12(1):5-20.

20. Qu L, Edwards B, Gray M: Ageing parent carers of people with a disability. Commonwealth of Australia: Canberra; 2012.

21. Bittman M, Hill T, Thomson C: The impact of caring on informal carers' employment, income and earnings: a longitudinal approach. Australian Journal of Social Issues 2007, 2(2):255-272.

22. Leigh A: Informal care and labour market participation. Labour Econ 2010, 17:140-149.

23. Falkiner A: Who provides care? An event history analysis of the effect of sex and relationship status on the provision of informal care in Australia, Volume Conference Paper. Canberra: Australian National University; 2011.

24. Australian Bureau of Statistics: Information paper - basic confidentialised unit record file: survey of disability, ageing and carers 2003 (reissue). Canberra: Australian Bureau of Statistics; 2005.

25. Wannamethee G, Shaper A: Self-assessment of health status and mortality in middle-aged British men. Int J Epidemiol 1991, 20(1):239-245.

26. Eligibility for parental leave pay. [http://www.humanservices.gov.au/ customer/enablers/centrelink/parental-leave-pay/eligibility-for-parentalleave-pay]

27. Government A: A plan to simplify and streamline superannuation. 2006

28. Legislation: Age Discrimination Act 2004. [http://www.humanrights.gov. au/our-work/legal/legislation]

29. Russell L, Rubin G, Leeder S: Preventive health reform: what does it mean for public health? MJA [Debate] 2008, 188(12):4.

30. Commonwealth respite and carelink centres website. [http://www9. health.gov.au/ccsd/index.cfm]

31. Holland KE: Carers' perspectives on caring: a qualitative analysis of open-ended responses to the carer health and wellbeing index survey 2007. Canberra: Carers Australia; 2008.

32. Ageing in place: quality care for older Australians. [http://www.health.gov.au/ internet/publications/publishing.nsf/Content/health-investinginagedcare-reportindex.htm health-investinginagedcare-report-2.htm health-investinginagedcarereport-2-3.htm]

33. Department of Human Services: Payments for carers. Canberra: Australian Government; 2014

34. Employee rights with carer status, family responsibilities and parental status. [http://www.humanrightscommission.vic.gov.au/index.php/workersrights/carer-and-parental-status]

35. Government A: Families in Australia: 2008. Canberra: Department of the Prime Minister and Cabinet; 2008.

36. Council of Australian Governments (COAG) Reform Council: Chapter 6: caring responsibilities, Tracking equity: Comparing outcomes for women and girls across Australia. Canberra: COAG Reform Council; 2013.

37. Men and caring. [http://www.fightdementia.org.au/services/men-andcaring.aspx]

38. Rudd KM, Roxon NM: Fresh ideas, future economy: preventative health care for our families and future economy. The Australian Labour Party 2007, 27-28.

doi:10.1186/1471-2458-14-561

Cite this article as: Schofield et al: The impact of chronic conditions of care recipients on the labour force participation of informal carers in Australia: which conditions are associated with higher rates of non-participation in the labour force? BMC Public Health 2014 14:561.

\section{Submit your next manuscript to BioMed Central and take full advantage of:}

- Convenient online submission

- Thorough peer review

- No space constraints or color figure charges

- Immediate publication on acceptance

- Inclusion in PubMed, CAS, Scopus and Google Scholar

- Research which is freely available for redistribution
C Biomed Central 